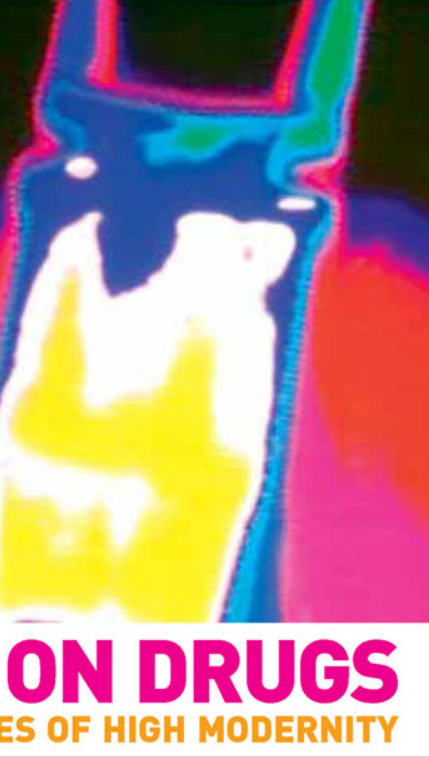

DAVE BOOTHROYD

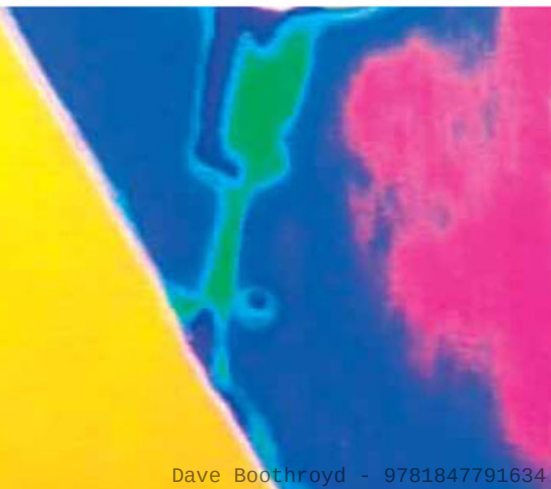

Downloaded from manchesterhive.com at 04/26/2023 01:25:57AM 


\section{Culture on drugs}

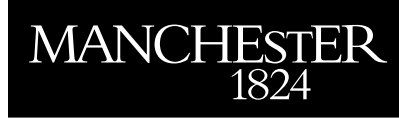

Manchester University Press 
This page intentionally left blank 


\title{
Culture on drugs
}

Narco-cultural studies of high modernity

\author{
Dave Boothroyd
}

\author{
Manchester University Press \\ Manchester and New York
}

distributed exclusively in the USA by Palgrave 
Copyright (C) Dave Boothroyd 2006

The right of Dave Boothroyd to be identified as the author of this work has been asserted by him in accordance with the Copyright, Designs and Patents Act 1988.

Published by Manchester University Press

Oxford Road, Manchester M13 9NR, UK

and Room 400, 175 Fifth Avenue, New York, NY 10010, USA

www.manchesteruniversitypress.co.uk

Distributed exclusively in the USA by

Palgrave, 175 Fifth Avenue, New York,

NY 10010, USA

Distributed exclusively in Canada by

UBC Press, University of British Columbia, 2029 West Mall,

Vancouver, BC, Canada V6T 1Z2

British Library Cataloguing-in-Publication Data

A catalogue record for this book is available from the British Library

Library of Congress Cataloging-in-Publication Data applied for

ISBN 0719055989 hardback

EAN $\quad 9780719055980$

ISBN 0719055997 paperback

EAN 9780719055997

EISBN 9781847791634

First published 2006

$\begin{array}{llllllllll}15 & 14 & 13 & 12 & 11 & 10 & 09 & 08 & 07 & 06\end{array}$

10988765543321

Typeset in Minion and Rotis display

by Koinonia, Manchester

Printed in Great Britain

by Bell \& Bain Ltd, Glasgow 